\title{
Pengembangan media edukasi diabetes mellitus untuk tenaga kefarmasian di puskesmas wilayah Mataram
}

\author{
Ni Made Amelia Ratnata Dewi ${ }^{1 *}$, Iman Surya Pratama ${ }^{1}$, Candra Dwipayana Hamdin ${ }^{1}$ \\ 1Program Studi Farmasi, Fakultas Kedokteran, Universitas Mataram, Mataram, Indonesia.
}

DOI: https://doi.org/10.29303/indra.v2i1.89

\section{Article Info}

Received : 11-03-2021

Revised : 24-04-2021

Accepted: 26-04-2021

\begin{abstract}
Adherence in using drugs is one of the factors that determine the success of therapy, especially for chronic diseases such as diabetes mellitus. Efforts that can be made by health workers in increasing adherence to diabetes mellitus sufferers in undergoing treatment are to pay attention to providing information and education to patients. The purpose of this community service activity is to develop educational media for type II diabetes mellitus for pharmaceutical workers in the Mataram regional health center. Making diabetes education media is done by making a pocket book which aims to make it easier for health workers to carry out counseling related to diabetes mellitus and its treatment.
\end{abstract}

Keywords: diabetes melitus, education, primary health care.

Citation: $\quad$ Dewi, N.M.A.R., Pratama, I.S., Hamdin, C.D. (2021) Pengembangan Media Edukasi Diabetes Mellitus untuk Tenaga Kefarmasian di Puskesmas Wilayah Mataram. INDRA Jurnal Pengabdian kepada Masyarakat, 2(1), 8-11. doi: https://doi.org/10.29303/indra.v2i1.89

\section{Pendahuluan}

Tingkat Kejadian global penderita Diabetes mellitus (DM) pada tahun 2017 adalah sebanyak 424,9 juta kasus atau sebesar $8,8 \%$ dari keseluruhan penduduk di dunia. Indonesia merupakan negara menempati urutan ke 6 dengan penderita DM sejumlah 10,3 juta(IDF, 2017). Pada Tahun 2016 dilaporkan bahwa diabetes mellitus menempati urutan ke 4 sebagai penyakit yang sering dialami oleh masyarakat Provinsi Nusa Tenggara Barat khususnya Kota Mataram (Dinkes NTB, 2017).

DM dideskripsikan sebagai penyakit gangguan metabolisme kronis yang ditandai dengan kondisi hiperglikemia. DM dapat terjadi karena tidak diproduksinya insulin, kurangnya insulin, atau resistensi insulin dan gangguan hormon lainnya. Hal ini akan berdampak pada ketidakmampuan untuk mengubah glukosa menjadi energi. Jika kondisi ini terjadi terus menerus akan dapat mengakibatkan komplikasi makrovaskular, mikrovaskular dan neuropatik (Sease \& Shealey, 2016). Diabetes mellitus dapat meningkatkan resiko timbulnya penyakit lain karena komplikasi, seperti penyakit kardiovaskular, kebutaan, gagal ginjal dan gangren (Armstrong, \& Lawrence, 2007).

Diabetes yang tidak terkontrol dapat mengakibatkan terjadinya hiperglikemia yang dapat menyebabkan kerusakan pada berbagai organ seperti jantung, ginjal, mata, pembuluh darah dan saraf. Hipergikemia dapat terjadi mengakibatkan gangguangangguan kesehatan lain seperti disfungsi ereksi dan infeksi jamur. Jika berlangsung lama hiperglikemia dapat berkembang menjadi keadaan metabolisme yang berbahaya, antara lain ketoasidosis diabetik yang dapat berakibat fatal bahkan mengakibatkan kematian. Selain itu diabetes mellitus juga dapat mengakibatkan terjadinya komplikasi makrovaskular seperti penyakit jantung koroner, penyakit pembuluh darah otak, dan penyakit pembuluh darah perifer (Depkes RI, 2005). Diabetes mellitus dapat dikontrol dengan mengubah gaya hidup seperti melakukan aktivitas fisik secara 
rutin, mengatur pola makan, menjaga berat badan, kepatuhan terhadap terapi obat, mengurangi konsumsi alkohol dan merubah kebiasaan merokok (B. S. et al., 2017).

Kepatuhan dalam menggunakan obat merupakan salah satu faktor yang menentukan keberhasilan terapi, terutama untuk penyakit kronis seperti diabetes melitus (Aronson, 2007). Ketidakpatuhan dalam menggunakan obat merupakan salah satu faktor yang dapat memperburuk kondisi diabetes mellitus. Pengetahuan penderita DM tentang penyakitnya kemungkinan akan meningkatkan kesadaran penderita untuk mengendalikan DM (Perkeni, 2015). Kegagalan terapi sering disebabkan karena kurangnya pengetahuan dan pemahaman pasien tentang obat dan segala sesuatu yang berhubungan dengan obat untuk terapinya (Wijaya et al., 2015).

Upaya yang dapat dilakukan oleh petugas kesehatan dalam meningkatkan kepatuhan penderita DM dalam menjalani pengobatan adalah dengan memberikan suatu perhatian dalam pemberian informasi serta edukasi kepada pasien. Penerapan komunikasi dalam pelayanan kesehatan mempunyai peran yang sangat besar terhadap kemajuan kesehatan pasien. Berdasarkan latar belakang tersebut, perlu dilakukan pengabdian untuk membuat suatu media edukasi tentang terapi diabetes mellitus untuk tenaga kefarmasian di puskesmas.

\section{Metode}

Metode pelaksanaaan kegiatan dalam pengabdian ini dibagi ke dalam beberapa tahap antara lain:

1. Orientasi

Orientasi merupakan tahap awal yang dilakukan bertujuan untuk mengetahui keadaan puskesmas. Pada tahap ini dilakukan penilaian tentang hal-hal yang dibutuhkan di puskesmas terkait dengan terapi penyakit diabetes mellitus.

2. Perancangan modul

Setelah diketahui kebutuhan puskesmas terkait terapi diabetes mellitus, dilakukan pemilihan media yang sesuai untuk kondisi di puskesmas serta merancang outline dan isi dari media.

3. Diskusi dengan tenaga kesehatan di puskesmas Rancangan yang telah dibuat, akan diperlihatkan terlebih dahulu kepada tenaga kesehatan yang akan menggunakan. Tenaga kesehatan dapat memberikan saran terkait rancangan modul yang telah dibuat.

4. Penyempurnaan modul

Proses penyempurnaan modul dilakukansetelah memperoleh masukan dari tenaga kesehatan. ini bertujuan untuk melakukan finalisasi atau penyempurnaan akhir yang komprehensif terhadap media, sehingga media siap diproduksi sesuai dengan masukkan yang diperoleh dari kegiatan sebelumnya.

5. Evaluasi

Setelah media dicetak, maka dilakukan evaluasi terhadap media tersebut. Evaluasi dilakukan dengan memberikan kuisioner kepada pengguna media.

\section{Hasil dan Pembahasan}

Pelaksanaan kegiatan pengabdian masyarakat ini dilaksanakan sejak bulan Agustus 2019. Kegiatan dimulai dengan mengirimkan surat untuk ijin melaksanakan pengabdian. Pada saat itu juga dilakukan komunikasi terhadap tenaga kesehatan dan tenaga kefarmasian terkait kebutuhan isi dari media edukasi tentang penyakit diabetes mellitus. Kemudian diketahui bahwa diperlukan suatu media yang berisikan materi terkait pengetahuan dasar terhadap penyakit diabetes mellitus. Hal ini disebabkan masyarakat awam masih memiliki pengetahuan yang kurang terhadap penyakit itu sendiri.

Setelah melakukan diskusi dengan tim pembuat modul dan pihak puskesmas, tim pengabdian masyarakat sepakat untuk membuat buku saku tentang penyakit diabetes mellitus. Buku saku ini berisi tentang definisi, prevalensi, penyebab dan faktor resiko, diagnosa serta cara pengendalian penyakit diabetes mellitus. Buku juga akan dilengkapi dengan cara minum obat diabetes mellitus serta efek samping dari pemakaian obat diabetes. Penyusunan buku saku berlangsung selama 3 bulan. Buku saku selesai dibuat pada akhir bulan Oktober dan diuji coba digunakan pada bulan November.

Draft buku saku yang telah dibuat kemudian dikonsultasikan kembali kepada pihak puskesmas, untuk melihat apakah ada diperlukan perbaikanperbaikan. Tenaga kesehatan di puskesmas diberikan angket terkait isi buku saku dalam angket juga diiisi saran yang diperlukan untuk buku saku yang telah dirancang. Bentuk form evaluasi dapat dilihat pada Gambar 1.

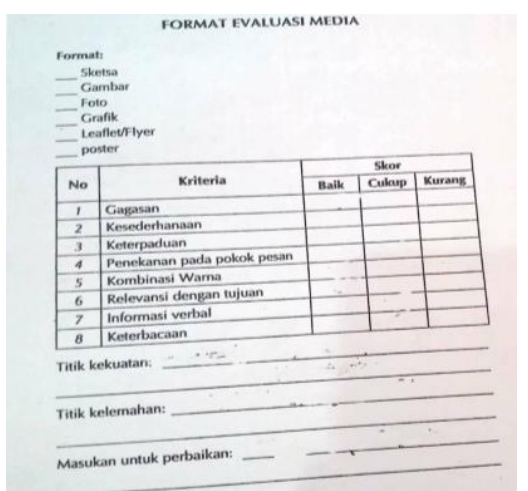

Gambar 1. Formulir Evaluasi Buku Saku 
Sebagian besar responden tenaga kesehatan yang mengisi angket mengatakan bahwa buku saku sudah baik namun perlu disederhanakan lagi karena terdapat beberapa bahasa yang kemungkinan sulit dimengerti oleh orang awam. Bahasa yang terlalu tinggi kemungkinan akan mengakibatkan kesulitan tenaga kesehatan untuk menjelaskannya.

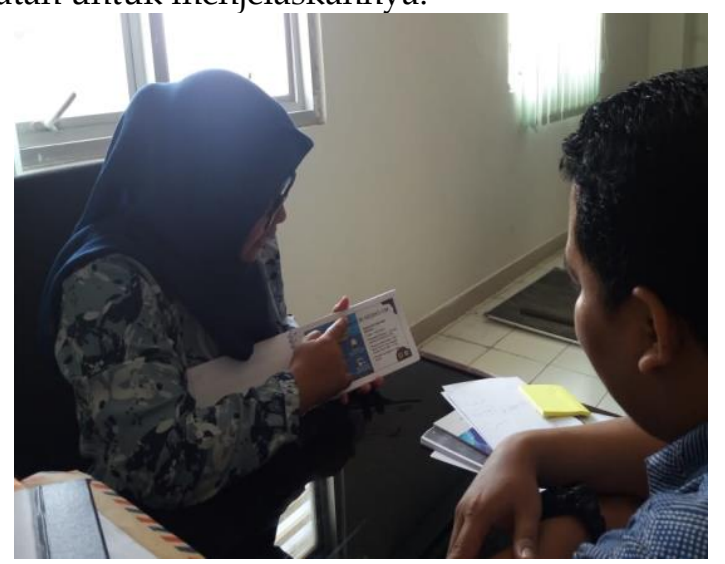

Gambar 2. Simulasi Penggunaan Buku Saku Diabetes Mellitus

Buku saku kemudian disederhanakan dan direvisi dengan menggunakan bahasa yang lebih mudah dimengerti oleh orang awam. Setelah revisi dilakukan, tim memfinalisasi draf dan mencetak buku saku tersebut. Buku saku yang telah tercetak kemudian dilakukan uji coba untuk digunakan pada pasien. Pasien merasa cukup mengerti dengan penyakit DM setelah diberikan konseling menggunakan buku saku tersebut.

Pada kegiatan pengabdian ini hanya dilakukan pembuatan media edukasi berupa buku saku, namun belum dilakukan pengujian terhadap efektivitas terhadap media tersebut terhadap pengetahuan dan kepatuhan dari pasien diabetes mellitus Pada sebuah penelitian yang dilakukan oleh Hidayah dan Sopiyandi di tahun 2018, didapatkan ada perbedaan pengetahuan setelah diberikan edukasi dengan media buku saku dan leaflet (Hidayah \& Sopiyandi, 2019). Perlu dilakukan pengujian efektivitas dari buku saku yang telah dibuat untuk kegiatan pengabdian yang selanjutnya.

\section{Simpulan}

Telah dilaksanakan kegiatan pengabdian masyarakat pembuatan media edukasi penyakit diabetes mellitus untuk tenaga kesehatan di Puskesmas Tanjung Karang, Kota Mataram, Provinsi NTB. Kegiatan berjalan dengan lancar sesuai dengan rencana.

\section{Ucapan Terima Kasih}

Kami mengucapkan terimakasih kepada tenaga Kesehatan di Puskesmas Tanjung Karang Mataram yang telah membantu terselenggaranya pengabdian ini. Boleh dicantumkan atau tidak, ucapan kepada pihak (institusi) yang mendukung terselenggaranya program.

\section{Daftar Pustaka}

Aronson, J. K. (2007). Compliance, Concordance, Adherence. British Journal of Clinical Pharmacology, 63(4), 383-384. Https:/ / Doi.Org/10.1111/J.13652125.2007.02893.X

Armstrong, D \& Lawrence, A. (2007). Diabetic foot ulcer prevention diagnosis and classification. Jakarta: EGC.

B. S., D., Subramanian, M., G., S., B. R., V., P., A., M., A., R., D., \& N., N. (2017). Knowledge Of Diabetes, Its Complications And Treatment Adherence Among Diabetic Patients. International Journal Of Community Medicine And Public Health, 4(7), $2428 . \quad$ Https://Doi.Org/10.18203/23946040.Ijcmph20172836

Departemen Kesehatan Republik Indonesia. (2005). Pharmaceutical Care Untuk Penyakit Diabetes Mellitus. Direktorat Jenderal Bina Kefarmasian Dan Alat Kesehatan Departemen Kesehatan RI . Jakarta.

Dinas Kesehatan Nusa Tenggara Barat. (2017). Profil Kesehatan Nusa Tenggar Barat 2016. Mataram: Dinas Kesehatan Kota Mataram. Mataram

Hidayah, M., \& Sopiyandi, S. (2019). Efektifitas Penggunaan Media Edukasi Buku Saku Dan Leaflet Terhadap Pengetahuan Dan Kepatuhan Diet Pasien Rawat Jalan Diabetes Melitus Tipe 2 Di Puskesmas. Pontianak Nutrition Journal (PNJ), 1(2), 66. Https:/ / Doi.Org/10.30602/Pnj.V1i2.290

IDF. (2017). IDF Diabetes Atlas. International Diabetes Federation.

Perkeni. (2015). Pengolahan Dan Pencegahan Diabetes Mellitus Tipe 2 Di Indonesia. Perkumpulan Endokrinologi Indonesia.

Sease, J., \& Shealey, K. (2016). Diabetes Mellitus. In Pharmacotherapy Principles \& Practice (4th Ed., P. 651). Mc Graw-Hill Companies.

Wijaya, I. N., Faturrohmah, A., Agustin, W. W., Soesanto, T. G., Kartika, D., \& Prasasti, H. 
(2015). Profil Kepatuhan Pasien Diabetes Melitus

Puskesmas Wilayah Surabaya Timur Dalam

Menggunakan Obat Dengan Metode Pill Count.

2(1), 5 . 